\title{
THE EFFECT OF USING EUCALYPTUS OIL, LEAVES, AND SEED CAPSULES AS SUPPLEMENT IN DIETS ON LACTATING EGYPTIAN BUFFALO PRODUCTIVITY AND METHANE PRODUCTION
}

\author{
F.M. Abo-Donia**1, A. Mahgoub ${ }^{1}$, T. Deraz ${ }^{1}$ and U.A. Nayel $^{2}$ \\ ${ }^{1}$ Agriculture By-product Utilization Research Department, Animal Production Research Institute \\ (APRI), Giza, Egypt.
}

${ }^{2}$ Faculty of Agriculture, Menoufia University, Egypt.

(Received 16/2/2021, accepted 28/4/2021)

\section{SUMMARY}

$\mathrm{S}$ ixteen lactating Egyptian buffaloes randomly assigned to a $4 \times 4$ Latin square design to investigate the effects of eucalyptus oil naturally protected in the form of leaves (EUL) or mature seed capsules (EUS) or unprotected crude oil (EUO). The control group (G1) got the basal diet consisting of concentrate feed mixture (CFM), fresh berseem (FB), rice straw (RS), and corn silage (CS) to be 40:60 concentrate: roughage ratio. In the G2, G3, and G4 animals fed the basal diet with a supplement of 200 $\mathrm{g} / \mathrm{head} /$ day of EUL, EUS, or $4 \mathrm{ml}$ EUO, respectively. Supplement of EUL or EUS increased NH $\mathrm{N}_{3} \mathrm{~N}, \mathrm{SCFA}$, and acetic acid concentrations in-vitro than EUO. While $\mathrm{C} 2 / \mathrm{C} 3$ ratio decreased $(\mathrm{P}<0.05)$ with supplement EUL or EUS compared to EUO or control diet. The total bacteria count, and cellulolytic bacteria increased $(\mathrm{P}<0.05)$ with supplement EUL or EUS, compared to EUO. While protozoa count increased with supplement EUO compared with EUL, EUS, or control. Methane production and degradability of NDF were lower $(\mathrm{P}<0.05)$ with the supplementation of EUS, EUL, or EUO compared to the control diet. Milk fat decreased $(\mathrm{P}<0.05)$ with EUO-supplement than the control diet, while an adverse trend was shown for lactose. No differences were found for feed conversion among EUS, EUL, or EUO. Total protein and albumin increased $(\mathrm{P}<0.05)$ with supplement EUL or EUS compared to EUO. Supplement EUO increased $(\mathrm{P}<0.05)$ AST, ALT, glucose, and creatinine. Blood urea increased $(\mathrm{P}<0.05)$ with feeding EUL or EUS compared to EUO, but no difference when compared to the control group. The supplementation of EUL, EUS, or EUO decreased $(\mathrm{P}<0.05) \mathrm{DM}, \mathrm{OM}$, and CP digestibility compared to the control diet. Digestibility of EE with EUL, EUS, or EUO was higher $(\mathrm{P}<0.05)$ than the control diet, while it was higher $(\mathrm{P}<0.05)$ with supplementing EUL or EUS than supplementing EUO to the diet. Digestibility of NDF and ADF decreased $(\mathrm{P}<0.05)$ with supplement EUL, EUS, or EUO compared to the control diet. Feeding EUS increased $(\mathrm{P}<0.05)$ digestibility of NDF and ADF compared to EUL supplementation, which was increased $(\mathrm{P}<0.05)$ than feeding EUO Feeding EUS increased values of TDN and DCP compared to EUL, which was higher than EUO. Finally, the results of the current study confirm that the effect of a supplement of EUO naturally protected in the form of leaves or seeds mitigates the negative effects of directly supplementing crude eucalyptus oil.

Keywords: Eucalyptus oil, eucalyptus leaves, eucalyptus seed capsules, methane, degradability, digestibility, milk production and buffalo.

\section{INTRODUCTION}

The rumen is a complex ecosystem in which the nutrients consumed by microorganisms at a suitable $\mathrm{pH}$ to provide the main products of fermentation, basically, short-chain fatty acids (SCFA's) and microbial biomass, which are used by the host ruminants (Cieslak et al. 2013 and Vakili, et al. 2013). Recently, there is increased interest in concerned with reducing the rate of rumen methane production.

Inasmuch methane $(\mathrm{CH} 4)$ production from enteric fermentation is of concern worldwide because of the increased accumulation of greenhouse gases in the atmosphere, as well as being a waste of nutritious energy (Sallam et al., 2010). There is an interesting to reduce $\mathrm{CH} 4$ release by inhibition of ruminal methanogens to increasing the efficiency of feed energy utilization by ruminants, these would have also improved economic efficiency and environmental (Benchaar and Greathead, 2011). Many studies were conducted to investigate the effects of supplementation levels of eucalyptus leaves and eucalyptus oil 
(EO) on methane production (McIntosh et al., 2003; and Castillejos et al., 2006), furthermore, much is still unknown about using dried or ground mature seeds. Sallam et al. (2010) hypothesized that EO could be used as a feed supplement to alter rumen biohydrogenation to reduce $\mathrm{CH} 4$ release and increase the flow of volatile acids (VA) to the duodenum. Abo-Donia and Nagpal (2015) reported that tannins have been shown to alter rumen biohydrogenation, while Sallam et al. (2010) stated that eucalyptus has an ionophores effect by affecting VA formation in the rumen through inhibiting the final step in the biohydrogenation of VA to stearic acid. Due to the volatile and reactive nature of EOs, it is possible that their effectiveness, when included in the animal's diet, may be affected according to different conditions during the production season, as well as storage of EOs and conditions in the digestive system of animals (Nguyen et al., 2009).

A recent study by Chouhan et al. (2017) shown that using EOs in a protected form has great potential effect for antimicrobial resistance due to increased chemical stability and solubility, reduced rapid evaporation, and reduced degradation of the active EOs. Also, Lammari et al. (2020) supported that the application of the encapsulation of EOs to make their release subject to continuous control enhancing their bioavailability and effectiveness against microbes.

In recent years, due to increasingly negative consumer perceptions, there has been an increase in interest in adding EOs in ruminant feeds to increase milk production and improve the animal's physiological performance (Thao et al., 2015). On the other hand, Turek and Stintzing (2013) suggested that adding such oils in their natural form, whether in the form of leaves or grains, avoids the negative effects of those crude oils and increases their effectiveness in ruminant nutrition.

However, there is a scarcity of knowledge of the effects of using naturally protected eucalyptus oil compared to using it as crude oil on animal performance (Maes et al., 2019). Therefore, this study aims to design new mixtures containing naturally protected eucalyptus oil compared to adding it in the form of crude oil and investigate the effect of adding these mixtures in dairy buffalo feed on methane production and production performance.

\section{MATERIALS AND METHODS}

This study was carried out according to the cooperation protocol between the Animal Production Research Institute (APRI), Agriculture By-product Utilization Research Department, and the Faculty of Agriculture, Menoufia University, the Animal Production Department, (Reference No. 2429.22.2019).

\section{Ingredients and the experimental diets:}

Eucalyptus leaves (EUL) and green mature seed capsules (EUS) collected from trees on beach canals were dried under shade for a week, then ground and stored at ambient room temperature until use. Eucalyptus oil (EUO) was obtained from "El Hawag for Natural Oils" - El Nasr City - Cairo, Egypt. Four experimental diets were formulated as total mixed ration isonitrogenous and iso-caloric to cover the recommended requirements of lactating buffaloes according to Kearl (1982). Animals in the $1^{\text {st }}$ group (G1) got the basal diet consisting of concentrate feed mixture (CFM), fresh berseem (FB), rice straw

Table (1): Chemical composition of ingredients and the experimental diet (\%) on a DM basis.

\begin{tabular}{|c|c|c|c|c|c|c|c|c|c|c|}
\hline \multirow[b]{2}{*}{ Item } & \multicolumn{6}{|c|}{ Ingredients } & \multicolumn{4}{|c|}{ Experimental diets } \\
\hline & CFM & $\mathrm{BF}$ & $\mathrm{RS}$ & $\mathrm{CS}$ & EUL & EUS & G1 & G2 & G3 & G4 \\
\hline $\mathrm{OM}$ & 91.06 & 86.97 & 83.18 & 92.11 & 95.07 & 94.93 & 88.09 & 88.76 & 88.76 & 88.09 \\
\hline $\mathrm{CP}$ & 16.35 & 15.07 & 2.69 & 8.62 & 8.63 & 12.94 & 12.28 & 12.37 & 12.34 & 12.28 \\
\hline NDF & 55.65 & 34.78 & 73.41 & 60.00 & 60.82 & 62.01 & 53.78 & 54.21 & 54.20 & 53.78 \\
\hline ADF & 38.26 & 23.91 & 48.64 & 45.64 & 50.01 & 51.82 & 36.86 & 37.22 & 37.21 & 36.86 \\
\hline $\mathrm{EE}$ & 3.62 & 2.34 & 1.19 & 2.58 & 5.92 & 7.85 & 2.60 & 2.89 & 2.86 & 2.90 \\
\hline Ash & 8.94 & 13.03 & 16.82 & 7.89 & 4.93 & 5.07 & 11.91 & 11.24 & 11.24 & 11.91 \\
\hline
\end{tabular}


(RS), and corn silage (CS) to be 40:60 concentrate: roughage ratio. The $2^{\text {nd }}(\mathrm{G} 2), 3^{\text {rd }}(\mathrm{G} 3)$, and $4^{\text {th }}(\mathrm{G} 4)$ groups fed the basal diet with a supplement of $200 \mathrm{~g} / \mathrm{head} /$ day of EUL, EUS, or $4 \mathrm{ml}$ EUO, respectively. Supplemented EUL, EUS, or EUO were dissolved daily in 1 liter of tap water, then blended and mixed directly with the concentrated feed to ensure consistency. Weekly homogeneous samples of experimental diets were dried and ground, then held in glass bottles for analysis and in-vitro studies. The chemical composition of ingredients and the experimental diets are presented in Table (1).

\section{Animals and management:}

A total number of 16 healthy lactating Egyptian buffalo (body weight: $457.4 \pm 10.5 \mathrm{~kg}$; parity: 2 to 4; 14 day in lactation) were divided into four similar groups randomize according to their previous milk records using quadratic $4 \times 4$ Latin squares experimental designs. Animals were individually fed the experimental diets twice daily ( 8 a.m. and 6 p.m.), Diet was offered for 28 days ( 21 days as preliminary period +7 days as collection period) and diet was adjusted every week according to changes in body weight and milk production. Mineral salt blocks left for the animals to lick freely, as well as access to drinking water.

\section{In-vitro gas production and degradability:}

In-vitro gas production technique was conducted according to Theodorou et al. (1994) on obtained samples of the experimental diets. Rumen fluid was collected from two buffalo cows of each group before the morning meal using a stomach tube. About $600 \mathrm{mg}$ of tested sample $(1.0 \mathrm{~mm})$ were incubated with $60 \mathrm{~mL}$ of previously prepared buffered rumen fluid for each bottle $(1: 3 \mathrm{~mL} / \mathrm{mL}$ ) according to (Goering and Van Soest 1970) under continuous $\mathrm{CO}_{2}$ reflux in $100 \mathrm{~mL}$ calibrated glass bottle in a water bath maintained at $39^{\circ} \mathrm{C}$. Samples were incubated in quadratic together with four bottles containing only incubation medium (blank). Headspace gas pressure measured at 2, 4, 8, 16, 24, 36, and $48 \mathrm{~h}$. Results of kinetic parameters of GP(t) $(\mathrm{ml} / \mathrm{g} \mathrm{DM})$ were fitted using the NLIN option according to (France et al., 2000) as:

$$
G \mathbf{v}_{(t)}=b x\left(1-\mathrm{e}^{-c(t-L)}\right)
$$

Where: $\mathrm{Gv}_{(t)}$ is the gas produced at time $t,{ }^{\prime} b$ ' is the asymptotic gas produced ( $\left.\mathrm{ml} / \mathrm{g} \mathrm{DM}\right)$ by the insoluble but slowly fermenting fraction, ' $c$ ' is constant gas production rate $(\mathrm{ml} / \mathrm{h})$, ' $t$ ' is time of fermentation and ' $\mathrm{L}$ ' is lag time.In-vitro $\mathrm{CH}_{4}$ produccion was determine as described by Pellikaan et al. (2011).

After termination of the incubation, bottle content was used for determination of in-vitro neutral detergent fiber degradability (IVNDFD). In-vitro liquor from each bottle was collected after filtration to determine $\mathrm{pH}$ using a portable $\mathrm{pH}$ meter, the concentration of $\mathrm{NH}_{3}-\mathrm{N}$ according to AOAC (2016), and total short-chain fatty acids (SCFA's) according to Eadie et al. (1967). Molar proportions of acetic, propionic, and butyric concentrations were analyzed by gas-liquid chromatography (GC 2010, PerkinElmer), capillary column (HPINNOWAX, 30m_0.250 mm_0.25 mm). The counting of rumen ciliate protozoa was performed under a light microscope according to Dehority (2003). Bacteria and cellulolytic bacteria were counting according to Wanapat et al. (2000).

\section{Digestibility trial:}

The feces were collected directly from the rectum of all animals in each group once in the morning before feeding at the end of the collection period. Acid-insoluble ash (AIA) was used as an internal marker to estimate the digestibility of nutrients (Van Keulen and Young 1977). Feeds and fecal samples were dried at $60^{\circ} \mathrm{C}$ and ground to pass a 1-mm screen for analyze. Dry matter (DM), crude protein (CP), ash, and ether extract (EE) were determined according to the procedure of AOAC (2016). Neutral detergent fiber (NDF) was estimated according to Van Soest et al. (1991). Nutrient digestibility coefficients and the nutritive value were calculated from the equation stated by Schneider and Flatt (1975).

$$
\text { DM digestibility }(\%)=100-\quad \frac{(100 \times \text { AIA } \% \text { in feed })}{(\text { AIA } \% \text { in feces })}
$$

Digestibility of components $=\quad 100-\quad \frac{100 \times \text { AIA } \% \text { in feed } \times \text { component } \% \text { in feed }}{\text { AIA } \% \text { in feces } \times \text { component } \% \text { in feces }}$




\section{Milk production and composition:}

Lactating buffalo cows were milked twice daily (6:00 and 18:00) and milk production (MP) was recorded for individual buffalo during the collection period. Daily milk samples were mixed according to the ration of the morning and afternoon milk yield for each animal and stored at $-20{ }^{\circ} \mathrm{C}$ for analysis of milk protein, fat, and lactose using infrared Milko-Scan (133BN Foss Electric, Denmark). Ash was determined according to AOAC (2016), while total solids and solid not fat (SNF) were calculated as differences. Fat correct milk (FCM, 7\%) was calculated according to Raafat and Saleh (1962) using the following equation:

$$
\mathrm{FCM}=[(0.265 \mathrm{x} \text { milk yield, } \mathrm{kg})+(10.5 \mathrm{x} \text { fat yield, } \mathrm{kg})]
$$

The yield of energy corrected milk (ECM) was calculated using fat and protein (adjusted to $3.5 \%$ fat and $3.2 \%$ protein) by the following formula (Casasús, et.al., 2004):

$$
\mathrm{ECM}(\mathrm{kg})=\text { Milk production }(\mathrm{kg}) \times(383 \times \text { fat } \%+242 \times \text { protein } \%+783.2) / 3140 \text {. }
$$

\section{Blood samples:}

Blood samples were obtained in the morning from the jugular vein of each animal of experimental groups before access to feed on at the final day of the collection period. Blood samples were centrifuged at $4000 \mathrm{rpm} / 15 \mathrm{~min}$ to separate the serum, then stored at $-18^{\circ} \mathrm{C}$ until analysis. Total proteins, albumin, urea nitrogen (BUN), aspartate aminotransferase (AST), alanine aminotransferase (ALT), creatinine, and glucose concentration determined using commercial kits, (Bio Merieux 69280 Marcy-1, Etoile/France) according to the manufacturer's instructions.

\section{Statistical analysis:}

In-vitro gas production data were analyzed using Statistical Analytical System (SAS, 2009), according to the General Linear Model as following: $Y_{i j}=\mu+T_{i}+e_{i j}$

Where: $\quad Y_{i j}=$ the observation; $\mu=$ Overall mean; $T_{i}=$ the fixed effect of the treatments; $e_{i j}=$ Random error term common for all observations. All obtained data of feeding experiments were subjected to analysis of variance according to a $4 \times 4$ Latin square design using the general linear model's procedures of the Statistical Analysis System Institute (SAS, 2009). The results are presented as mean values with the standard error of the means. Differences among means with $\mathrm{p}<0.05$ were accepted as representing statistical differences. Treatment means were compared by orthogonal polynomials by Duncan's (1955) New Multiple Range Test.

\section{RESULTS AND DISCUSSION}

\section{In-vitro ruminal fermentation characteristics and gas production kinetic:}

As shown in Table (2), the $\mathrm{pH}$ value of an in-vitro incubated diet in $(\mathrm{G} 4)$ was increased $(\mathrm{P}<0.05)$ significantly compared to other experimental diets. Reduced the $\mathrm{pH}$ values with the supplement of eucalyptus oil to a diet during in-vitro incubation was in line with the value of low rumen $\mathrm{pH}$ observed by several studies (Sallam et al., 2010; Wang et al., 2009; Thao et al. 2014). While no effect was observed on rumen $\mathrm{pH}$ with supplemental EUL or EUS to buffalo diet which corresponds to results obtained by Manh et al. (2012); Thao et al. (2015). These results suggested that supplemental eucalyptus oil naturally protected in the leaves or seed reduces the negative effect of supplement eucalyptus crude oil.

The $\mathrm{NH}_{3}-\mathrm{N}$, SCFA's and acetic acid concentrations decreased $(\mathrm{P}<0.05)$ significantly in G4 than $\mathrm{G} 1$, G2, and G3. The propionic acid concentrations of incubated rumen liquor in G2 and G3 were increased $(\mathrm{P}<0.05)$ significantly compared to $\mathrm{G} 4$ and $\mathrm{G} 1$. The butyric acid concentrations of incubated rumen liquor in $\mathrm{G} 3$ were increased $(\mathrm{P}<0.05)$ significantly compared to $\mathrm{G} 1, \mathrm{G} 2$ and $\mathrm{G} 4$. However, $\mathrm{C} 2 / \mathrm{C} 3$ ratio decreased $(\mathrm{P}<0.05)$ significantly in $\mathrm{G} 2$ and $\mathrm{G} 3$ compared to $\mathrm{G} 4$ and $\mathrm{G} 1$. These findings agree with that mentioned by Vakili et al., (2013) and Thao et al., (2015). Castillejos et al. (2006) found that EUO supplementation for the long-term led to a reduction in rumen ammonia-N compared to those in the control diet. Moreover, Patra and Saxena (2009) suggested that essential crude oils may inhibit bacteria producing excess ammonia in the rumen, resulting in reduced consequently amino acid deamination, thus lowering rumen $\mathrm{NH}_{3}-\mathrm{N}$. McIntosh et al. (2003) demonstrated that EUO inhibited the growth of some bacteria species (i.e., Clostridium sticklandii and Peptostreptococcus anaerobius) hyper-ammonia producing, but other bacteria species such as Clostridium aminophilum were less sensitive. Hyper- 
ammonia-producing bacteria are present in low numbers in the rumen $(\mathrm{P}<0.01)$ of the rumen bacterial population, but they possess a very high deamination activity (Castillejos et al. (2006). Patra and Saxena (2010) and Vakili et al. (2013) reported that high levels of EUO supplementation led to a slight reduction in concentrations of total SCFA's in the rumen. Similar findings were observed by Wang et al. (2009) when used EUO supplementation in the sheep diet. McIntosh et al. (2003) reported that the effect of EUO supplementation in the rumen was attributed to chemical structures and bioactive components.

Results of the present study noted that supplemented EUO to buffalo cows diets led to an alteration in the end products of rumen fermentation with a drop of acetate which was previously reported by Castillejos et al. (2006) and Giannenas et al. (2011).

Supplementation of EUO to the in-vitro incubated diet in G4 led to reduced $(\mathrm{P}<0.05)$ the total count of bacteria and cellulolytic bacteria than those in G2, G3, or G1. The total count of bacteria was not different significantly in G1, G2, and G3 but cellulolytic bacteria count was lower $(\mathrm{P}<0.05)$ in G3 than G1. Conversely, protozoa count was increased $(\mathrm{P}<0.05)$ significantly with EUO supplementation $(\mathrm{G} 4)$ compared to the supplementation of EUL (G2), EUS (G3), or control (G1). Cobellis, et al., (2015) agreed on the result obtained in this study, which indicates a decrease in the feed degradability in the rumen, which attributed to the non-selective antimicrobial activities of supplemented EOs affecting a wide range of microbial subgroups such as, cellulolytic bacteria. Furthermore, Patra and Yu (2012) found that supplement of all the tested EOs of clove, eucalyptus, garlic, oregano, and peppermint reduce the abundance of rumen archaea and protozoa, especially in that of cellulolytic bacteria.

As illustrated in Fig. (1), the cumulative gas volume (calculated as a means for all incubation times) was significantly lower $(\mathrm{P}<0.05)$ for all treated diets $(\mathrm{G} 2, \mathrm{G} 3$, and $\mathrm{G} 4)$ than for the control one $(\mathrm{G} 1)$. The lowest volume of gas produced was recorded with EUO (G4) followed by those in-vitro incubated diets with EUL (G2) and EUS (G3) (Table 2).

Table (2): Effect of leaves, seeds and eucalyptus oil supplementation on in-vitro gas cumulative, methane production, and NDF degradability.

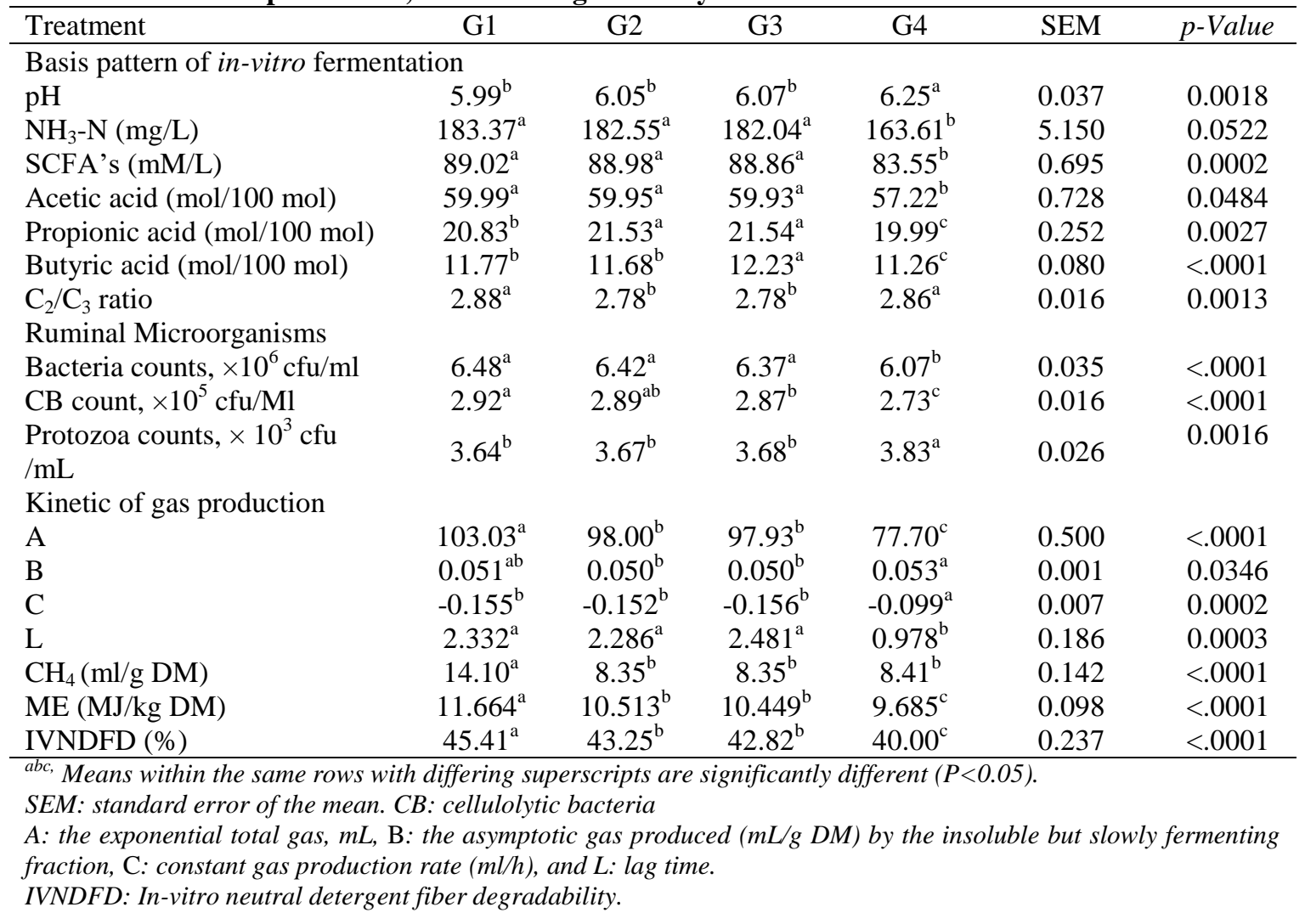

The values of insoluble but slowly fermenting fraction (b) and constant gas production rate (c) significantly $(\mathrm{P}<0.05)$ increased with EUO supplementation $(\mathrm{G} 4)$ than other experimental diets. Otherwise, Lag time significantly $(\mathrm{P}<0.05)$ reduced with EUO supplementation (G4) than other 
experimental diets. All studied Supplementations (EUL, EUS, or EUO) led to a significant decrease $(\mathrm{P}<0.05)$ in methane production and Degradability of IVNDFD compared to the control diet. Findings of this study show that all supplemented forms of eucalyptus decrease $(\mathrm{P}<0.05)$ methane and total gas production. In the same line, Cieslak et al. (2013) stated that EOs supplemented to ruminant diets have altered digestion and fermentation, and methanogenesis of diets in the rumen by microbial populations. Sallam et al. (2010) suggest that the potential effect of supplementation fresh and residual eucalyptus leaves into the diets on mitigating the in-vitro $\mathrm{CH}_{4}$ production, may be attributed to a decrease in fermentable substrate rather than to a direct effect on methanogenesis Analogous results were observed by Manh et al. (2012) in cows that received $100 \mathrm{~g} /$ day of eucalyptus leaf meal and led to mitigating of rumen $\mathrm{CH}_{4}$ emission. Moreover, Patra and $\mathrm{Yu}$ (2012) reported a drop in methane production by less than $15 \%$ with using eucalyptus extract than the control group.



Fig. (1): Accumulative gas volume $\left(\mathbf{G v}_{(\mathrm{t})}\right)$ for the experimental diets at different incubation times.

\section{Feed intake, feed conversion and milk yield and composition:}

Table (3) shows that supplementary form of eucalyptus (EUS, EUL, or EUO) to buffalo diet led to a significant $(\mathrm{P}<0.05)$ decrease in milk production $(\mathrm{MP})$, fat corrected milk $(\mathrm{FCM}) 7 \%$, and energy corrected milk (ECM) than the control diet. Buffalo cows in G4 had the lowest values of MP, FCM 7\%, and ECM followed by buffalo cows in G2 and G3. Several studies implied the effect of supplement eucalyptus leaves and others used eucalyptus oil on feed intake and palatability, but their results were variable and inconsistent (Ahmed et al., 2005; Hristov et al., 2013). The confirmed results show that supplementing EUS, EUL and EUO did not affect DMI. Similar findings were recorded by Benchaar et al. (2007); Vakili et al. (2013) and Hristov et al. (2013), while, Giannenas et al. (2011) stated that the amount of feed intake depends on the dose of EOs supplementation. On the other hand, Cardozo et al., (2006) reported that EUO supplementation decreases DMI. The effects of eucalyptus supplementation on DMI may differ with the eucalyptus source, diet type, diet interactions, or adaptation of rumen microbial groups (Yang et al., 2010b).

Feed conversion values as mentioned as DMI/FCM, TDNI/FCM, and NI/FCM increased $(\mathrm{P}<0.05)$ significantly by either supplementary form of eucalyptus to experimental diets than control one. Supplement of either EUL and EUS in G2 and G3 appeared preferred values of feed conversion compared to EUO supplementation in G4. Sebei et al., (2015) reported that the major component of the EOs in eucalyptus is 1,8-cineole followed by $\alpha$-pinene. An increased feed conversion efficiency was observed when dairy cows were supplemented with eucalyptus leaf material (Thao et al., 2015) and also with eucalyptus oil (Giller et al., 2020; Al-Suwaiegh et al., 2020). 
Milk production as MP and ECM was significantly $(\mathrm{P}<0.05)$ decreased in experimental groups than the control group, also milk fat was significantly $(\mathrm{P}<0.05)$ decreased in $\mathrm{G} 4$ than the other experimental groups, while an adverse trend was obtained for the milk content of lactose, while contents of proteins, ash, SNF and TS were not affected $(\mathrm{P}<0.05)$ significantly by supplementing EUS or EUL. A reverse result was recorded by Giannenas et al. (2011) who refer to an increase in milk production with EOs supplementation into diets of dairy ewes. Effects of EOs supplementation on the contents of protein, fat, and lactose in the milk are very contradictory. Some studies reported an increase in milk protein content (Spanghero et al., 2009; Wall et al., 2014), but others show an increase in milk fat (Santos et al., 2010), while other studies found an increase in milk Lactose (Benchaar et al., 2007) when dairy cows and ewes diets supplemented with EOs.

Table (3): Effect of leaves, seeds and eucalyptus oil supplementation on milk production, its constituents and feed conversion.

\begin{tabular}{|c|c|c|c|c|c|c|c|c|}
\hline \multirow{2}{*}{ Item } & \multicolumn{4}{|c|}{ Experimental diets } & \multirow{2}{*}{ SEM } & \multicolumn{3}{|c|}{$p$-Value } \\
\hline & G1 & $\mathrm{G} 2$ & G3 & G4 & & $\mathrm{T}$ & $\mathrm{P}$ & $\mathrm{T} \times \mathrm{P}$ \\
\hline TDMI $(\mathrm{kg} / \mathrm{h} / \mathrm{d})$ & 15.956 & 16.137 & 16.135 & 15.964 & 0.133 & 0.6265 & 0.2937 & 0.7791 \\
\hline $\operatorname{MP}(\mathrm{kg} / \mathrm{h} / \mathrm{d})$ & $7.00^{\mathrm{a}}$ & $6.84^{\mathrm{b}}$ & $6.80^{\mathrm{b}}$ & $6.54^{\mathrm{c}}$ & 0.047 & $<.0001$ & 0.8900 & 0.6526 \\
\hline $\mathrm{FCM}(\mathrm{kg} / \mathrm{h} / \mathrm{d})$ & $6.38^{\mathrm{a}}$ & $6.19^{\mathrm{b}}$ & $6.10^{\mathrm{b}}$ & $5.82^{c}$ & 0.059 & $<.0001$ & 0.9926 & 0.9713 \\
\hline $\mathrm{ECM}(\mathrm{kg} / \mathrm{h} / \mathrm{d})$ & $9.04^{\mathrm{a}}$ & $8.78^{\mathrm{b}}$ & $8.66^{\mathrm{b}}$ & $8.24^{c}$ & 0.068 & $<.0001$ & 0.9969 & 0.8982 \\
\hline \multicolumn{9}{|c|}{ Milk composition $(\%)$} \\
\hline Fat & $6.16^{\mathrm{a}}$ & $6.08^{\mathrm{ab}}$ & $6.02^{\mathrm{ab}}$ & $5.95^{\mathrm{b}}$ & 0.060 & 0.1013 & 0.7209 & 0.6964 \\
\hline Protein & 3.78 & 3.78 & 3.77 & 3.69 & 0.031 & 0.2065 & 0.6721 & 0.8121 \\
\hline Lactose & $4.54^{\mathrm{b}}$ & $4.57^{\mathrm{ab}}$ & $4.66^{\mathrm{ab}}$ & $4.72^{\mathrm{a}}$ & 0.050 & 0.0612 & 0.3893 & 0.8416 \\
\hline Ash & 1.39 & 1.38 & 1.38 & 1.38 & 0.018 & 0.9647 & 0.9634 & 0.1685 \\
\hline SNF & 9.71 & 9.73 & 9.80 & 9.79 & 0.061 & 0.6439 & 0.2387 & 0.4375 \\
\hline TS & 15.87 & 15.82 & 15.82 & 15.74 & 0.071 & 0.6798 & 0.5617 & 0.9866 \\
\hline \multicolumn{9}{|c|}{ Feed conversion (kg intake/kg FCM 7\% fat) } \\
\hline $\mathrm{DMI} / \mathrm{FCM}$ & $2.503^{\mathrm{c}}$ & $2.616^{\mathrm{b}}$ & $2.649^{\mathrm{b}}$ & $2.746^{\mathrm{a}}$ & 0.032 & $<.0001$ & 0.6758 & 0.5986 \\
\hline TDNI/FCM & $1.563^{\mathrm{b}}$ & $1.642^{\mathrm{a}}$ & $1.633^{\mathrm{a}}$ & $1.609^{\mathrm{ab}}$ & 0.019 & 0.0333 & 0.6652 & 0.5867 \\
\hline NI/FCM & $0.049^{\mathrm{c}}$ & $0.052^{\mathrm{b}}$ & $0.053^{\mathrm{ab}}$ & $0.054^{\mathrm{a}}$ & 0.001 & $<.0001$ & 0.6015 & 0.6106 \\
\hline
\end{tabular}

${ }_{a b c,}$ Means within the same rows with differing superscripts are significantly different $(P<0.05)$. $S E M=$ standard error of the mean.

$M P=$ Milk production, FCM = Fat corrected milk 7\%, and ECM= Energy corrected milk.

SNF: solid not fat and, and TS: total solid.

\section{Nutrient digestibility and nutritive values:}

Data in Table (4) illustrated that the supplementation of EUL, EUS, or EUO to the buffalo diet significantly $(\mathrm{P}<0.05)$ decreased the digestion coefficient of $\mathrm{DM}, \mathrm{OM}, \mathrm{CP}, \mathrm{NDF}$, and ADF compared to the control diet. Also, the digestion coefficients of these parameters were significantly $(\mathrm{P}<0.05)$ higher in G2 and G3 than in G4. In contrast, the digestibility of EE in the experimental groups was increased $(\mathrm{P}<0.05)$ significantly compared with the control group. The nutritive values were significantly $(\mathrm{P}<0.05)$ affected by EUS, EUL, or EUO supplementation. Values of TDN for G3 and G4 were decreased $(\mathrm{P}<0.05)$ significantly than G1 and G2 and G4 had the lowest value of TDN. Also, G4 had the lowest value of DCP followed by G3 and G2, respectively and G1 had the highest value of DCP. For instance, the apparent digestibility of DM, OM, CP, NDF, and ADF were different ( $\mathrm{p}>0.05)$ among treatments in the study by Thao, et al. (2014; 2015). Moreover, Sallam et al. (2010) concluded that supplementation of EUO influences the digestibility of DM and OM in-vitro. Furthermore, Santos et al. (2010) found that feed digestibility was affected when the EOs compound was added to the diet of lactating dairy cows. Current results are supported by the results obtained by Benchaar et al. (2007) who shown that apparent total tract digestibilities of DM, CP, and NDF had been affecting lactating cows supplemented with $2 \mathrm{~g} /$ day of EOs. 
Table (4): Effect of leaves, seeds, and eucalyptus oil supplementation on apparent digestibility coefficients of experimental diets.

\begin{tabular}{|c|c|c|c|c|c|c|c|c|}
\hline \multirow{2}{*}{ Item } & \multicolumn{4}{|c|}{ Experimental diets } & \multirow{2}{*}{$\begin{array}{c} \pm \\
\text { SEM }\end{array}$} & \multicolumn{3}{|c|}{$p$-Value } \\
\hline & G1 & $\mathrm{G} 2$ & G3 & G4 & & $\mathrm{T}$ & $\mathrm{P}$ & $\mathrm{T} \times \mathrm{P}$ \\
\hline \multicolumn{9}{|c|}{ Nutrient digestibility (\%) } \\
\hline DM & $66.63^{\mathrm{a}}$ & $65.86^{\mathrm{a}}$ & $63.88^{\mathrm{b}}$ & $61.73^{\mathrm{c}}$ & 0.358 & $<.0001$ & 0.3414 & 0.4809 \\
\hline OM & $68.41^{\mathrm{a}}$ & $67.60^{\mathrm{b}}$ & $66.41^{\mathrm{c}}$ & $63.51^{\mathrm{d}}$ & 0.107 & $<.0001$ & 0.0101 & $<.0001$ \\
\hline $\mathrm{CP}$ & $70.62^{\mathrm{a}}$ & $69.43^{\mathrm{b}}$ & $67.33^{c}$ & $63.03^{\mathrm{d}}$ & 0.131 & $<.0001$ & 0.1097 & 0.1292 \\
\hline $\mathrm{EE}$ & $67.15^{\mathrm{c}}$ & $76.07^{\mathrm{a}}$ & $75.25^{\mathrm{a}}$ & $73.08^{b}$ & 0.462 & $<.0001$ & 0.7607 & 0.8997 \\
\hline NDF & $68.11^{\mathrm{a}}$ & $67.28^{\mathrm{b}}$ & $64.24^{\mathrm{c}}$ & $60.01^{\mathrm{d}}$ & 0.209 & $<.0001$ & 0.0409 & $<.0001$ \\
\hline $\mathrm{ADF}$ & $62.59^{\mathrm{a}}$ & $62.05^{\mathrm{b}}$ & $59.36^{\mathrm{c}}$ & $57.40^{\mathrm{d}}$ & 0.127 & $<.0001$ & $<.0001$ & $<.0001$ \\
\hline \multicolumn{9}{|c|}{ Nutritive values (\%) } \\
\hline TDN & $62.45^{\mathrm{a}}$ & $62.75^{\mathrm{a}}$ & $61.63^{\mathrm{b}}$ & $58.60^{\mathrm{c}}$ & 0.093 & $<.0001$ & 0.0109 & $<.0001$ \\
\hline DCP & $8.67^{\mathrm{a}}$ & $8.55^{\mathrm{b}}$ & $8.31^{\mathrm{c}}$ & $7.74^{\mathrm{d}}$ & 0.016 & $<.0001$ & 0.1179 & 0.1125 \\
\hline
\end{tabular}

\section{Blood metabolites:}

Table (5) shows that serum total protein and albumin significantly $(\mathrm{P}<0.05)$ increased in G2 and G3 compared to G4 or G1 and G4 had the lowest level of serum total protein. In the same context, (Morsy et al., 2012) found that the dietary supplementation of different EOs (anise, clove, and juniper) or their combination significantly increased total protein, albumin, and globulin. While Malekkhahi et al., (2015) stated that sheep fed garlic EO or lambs fed a combine (thymol, carvacrol, eugenol, limonene, and cinnamaldehyde) supplemented diet did not affect plasma total protein and albumin. Kirkpinar et al. (2011) supposed that the improvement of serum protein of animals fed EOs blend could be due to the content of phytochemicals, which immune stimulation and anti-inflammatory and antioxidative activities. Moreover, Yang et al., (2010b) has been reported that concentrations of some blood metabolites such as total protein and albumin can be influenced by EO kind via changing of feed intake and no change in glucose and creatinine concentration may be contributed to lack of DMI alternation by the EO.

On contrary, the concentration of AST and ALT in serum of buffalo cows fed a diet containing EUO (G4) significantly $(\mathrm{P}<0.05)$ increased. In opposite, the concentration of AST and ALT in serum of buffalo cows fed a diet containing EUO (G4) significantly $(\mathrm{P}<0.05)$ increased than the other experimental groups. The urea concentrations were significantly different between the supplementary groups and the control group, Serum urea significantly $(\mathrm{P}<0.05)$ decreased in $\mathrm{G} 4$ compared to the other experimental groups. Ruminal ammonia-N over microbial requirement is absorbed across the rumen wall into portal blood, and most of it is converted to urea in the liver. Therefore, the synthesis of urea in the liver is performed from ammonia absorbed from the rumen; as a result, urea $\mathrm{N}$ concentration in blood is highly correlated with the rumen $\mathrm{NH}_{3}-\mathrm{N}$ concentration (Davidson et al., 2003). This interpretation is consistent with the results obtained, as the concentrations of rumen NH3-N, Table (2), were not affected by the supplement of EUS and EUL, compared with the EUO supplement, which was reflected on BUN. Although the results disagree with those obtained from Yang et al. (2010a) that investigated different doses of EO in beef cattle but were consistent with some of what is obtained by Tassoul and Shaver (2009). Moreover, supplementation of EUO in the finishing diet of calves was expected to have pharmacological activity; however, these compounds did not affect the liver enzymes.

Serum glucose concentration was significantly $(\mathrm{P}<0.05)$ affected by supplementation type. Buffalo cows in G4 had the highest level of serum glucose concentration followed by buffalo cows in G3 and G2 respectively and the lowest level of serum glucose concentration was estimated in buffalo cows in G1. Many previous studies found that EOs supplementation did not affect significantly blood glucose concentration (Tassoul and Shaver, 2009; Yang et al., 2010b, and Vakili et al., 2013). While Malekkhahi et al. (2015) agree with the obtained result of glucose levels in this study that show alteration in glucose levels when goats and growing lambs fed different $\mathrm{EO}$ or EO blend. 
Creatinine in buffalo cows fed a diet containing EUS or EUO significantly $(\mathrm{P}<0.05)$ increased compared to those fed a basal diet (G1) or fed a diet containing EUL (G2). The results of the study conducted by Yang et al. (2010b) indicated an increase in the concentration of creatinine in the blood when adding eucalyptus leaves, eucalyptus oil, or EOs blend to the diet compared to the control group (Al-Suwaiegh et al., 2020). In contrast, Castillo et al. (2012) reported that the EOs bled (carvacrol, cinnamaldehyde, and capsaicin) supplementation decreased serum creatinine level in calves.

Table (5): Effect of leaves, seeds, and eucalyptus oil supplementation on blood parameters.

\begin{tabular}{|c|c|c|c|c|c|c|c|c|}
\hline \multirow{2}{*}{ Item } & \multicolumn{4}{|c|}{ Experimental diet } & \multirow{2}{*}{$\begin{array}{c} \pm \\
\text { SEM }\end{array}$} & \multicolumn{3}{|c|}{$p$-Value } \\
\hline & G1 & $\mathrm{G} 2$ & G3 & G4 & & $\mathrm{T}$ & $\mathrm{P}$ & $\mathrm{T} \times \mathrm{P}$ \\
\hline \multicolumn{9}{|l|}{ Blood parameters } \\
\hline Total protein (TP), g/dl & $6.04^{\mathrm{b}}$ & $6.12^{\mathrm{a}}$ & $6.13^{\mathrm{a}}$ & $5.98^{\mathrm{c}}$ & 0.009 & $<.0001$ & 0.6034 & 0.3950 \\
\hline $\operatorname{Albumin}(\mathrm{A}), \mathrm{g} / \mathrm{dl}$ & $3.04^{\mathrm{b}}$ & $3.15^{\mathrm{a}}$ & $3.15^{\mathrm{a}}$ & $3.00^{\mathrm{b}}$ & 0.027 & 0.0003 & 0.7482 & 0.0150 \\
\hline $\mathrm{AST}, \mathrm{u} / \mathrm{l}$ & $36.38^{\mathrm{b}}$ & $36.47^{\mathrm{b}}$ & $36.56^{\mathrm{b}}$ & $37.56^{\mathrm{a}}$ & 0.314 & 0.0394 & 0.7197 & 0.9019 \\
\hline ALT, $\mathrm{u} / \mathrm{l}$ & $16.06^{\mathrm{b}}$ & $16.10^{\mathrm{b}}$ & $16.16^{\mathrm{b}}$ & $16.59^{\mathrm{a}}$ & 0.145 & 0.0508 & 0.6927 & 0.0003 \\
\hline Urea (BUN), mg/dl & $15.39^{\mathrm{a}}$ & $15.22^{\mathrm{a}}$ & $15.23^{\mathrm{a}}$ & $14.10^{\mathrm{b}}$ & 0.073 & $<.0001$ & 0.1348 & 0.1178 \\
\hline Glucose, $\mathrm{mg} / \mathrm{dl}$ & $58.50^{\mathrm{d}}$ & $61.80^{\mathrm{c}}$ & $63.73^{\mathrm{b}}$ & $65.23^{\mathrm{a}}$ & 0.120 & $<.0001$ & 0.2217 & 0.1760 \\
\hline Creatinine, $\mathrm{mg} / \mathrm{dl}$ & $1.52^{\mathrm{b}}$ & $1.50^{\mathrm{b}}$ & $1.57^{\mathrm{a}}$ & $1.58^{\mathrm{a}}$ & 0.014 & 0.0003 & 0.0334 & 0.1999 \\
\hline
\end{tabular}

\section{CONCLUSION}

It could be inferred that EUS, EUL, and EUO supplementation in buffalo feed do not seem to have a protective effect on organ function associated with the blood measurements tested in this research, despite a slight decrease in milk production and fat content, so it is recommended to be careful about adding such substances to the animals diet. The results of the current study confirm that the effect of a supplement of EUO naturally protected in the form of leaves or seeds capsules mitigates the negative effects of directly adding EUO on nutrient digestibility, feeding value, milk yield and composition and blood parameters, where directly adding EUO reduces milk yield and the digestion coefficients of DM, OM, CP, EE, NDF, and ADF comparing with EUO naturally protected.

\section{DECLARATION OF COMPETING INTEREST:}

We declare that there is no conflict of interest in this project.

\section{ACKNOWLEDGMENTS}

The authors thank the Animal Production Research Institute and the Animal Production Department at the Faculty of Agriculture, Menoufia University, for providing all the supplies required by the research during conduct, including animals, laboratories, chemicals ... etc.

\section{REFERENCES}

Abo-Donia, F., and A. Nagpal (2015). In-vitro evaluation of moth (Phaseolus aconitifolius) fodder, khejri (Prosopis cineraria) leaves and their combinations in camel. Indian Journal of Animal Nutrition, 32; 192-197.

Ahmed, F.G., M. Yacout, and F. Abo-Donia (2005). Effect of using Eucalyptus globulus leaves in growing rabbits diets. Egypt. J. Rabbit Sci., 15; 1-11. 
Al-Suwaiegh, S.B., S.A. Morshedy, A.T. Mansour, M.H. Ahmed, S.M. Zahran, T.M. Alnemr and S.Sallam (2020). Effect of an essential oil blend on dairy Cow Performance during Treatment and Post-Treatment Periods. Sustainability., 12; 9123.

AOAC (2016). Association of official analyticed of chemists.

Benchaar, C., and H. Greathead (2011). Essential oils and opportunities to mitigate enteric methane emissions from ruminants. Animal Feed Science and Technology., 166; 338-355.

Benchaar, C., H.Petit, R. Berthiaume, D. Ouellet, J. Chiquette and P. Chouinard (2007). Effects of essential oils on digestion, ruminal fermentation, rumen microbial populations, milk production, and milk composition in dairy cows fed alfalfa silage or corn silage. Journal of Dairy science., 90; 886897.

Cardozo, P., S. Calsamiglia, A. Ferret and C. Kamel (2006). Effects of alfalfa extract, anise, capsicum, and a mixture of cinnamaldehyde and eugenol on ruminal fermentation and protein degradation in beef heifers fed a high-concentrate diet. Journal of Animal Science., 84; 2801-2808.

Casasús, I., A. Sanz, D. Villalba, R. Ferrer and R. Revilla (2004). Intake capacity of two breeds of suckler cattle of different milk yield potential and validation of prediction models. Livestock Production Science., 89; 195-207.

Castillejos, L., S. Calsamiglia and A. Ferret (2006). Effect of essential oil active compounds on rumen microbial fermentation and nutrient flow in in-vitro systems. Journal of dairy science., 89; 2649-2658.

Castillo, C., J.L. Benedito, P. Vázquez, V. Pereira, J. Méndez, J. Sotillo and J. Hernández (2012). Effects of supplementation with plant extract product containing carvacrol, cinnamaldehyde and capsaicin on serum metabolites and enzymes during the finishing phase of feedlot-fed bull calves. Animal feed science and technology., 171; 246-250.

Chouhan, S., K. Sharma and S. Guleria (2017). Antimicrobial activity of some essential oils-present status and future perspectives. Medicines., 4; 58.

Cieslak, A., M. Szumacher-Strabel, A. Stochmal and W. Oleszek, (2013). Plant components with specific activities against rumen methanogens. Animal., 7;253-265.

Cobellis, G., A. Petrozzi., C. Forte., G. Acuti, M. Orrù., M. Marcotullio., A. Aquino., A. Nicolini., V. Mazza and M. Marinucci (2015). Evaluation of the effects of mitigation on methane and ammonia production by using Origanum vulgare L. and Rosmarinus officinalis L. essential oils on in-Vitro rumen fermentation systems. Special Issue 15th CIRIAF National Congress - Environmental Footprint and Sustainable Development.

Davidson, S., B. Hopkins, D. Diaz, S. Bolt, C. Brownie, V. Fellner and L. Whitlow (2003). Effects of amounts and degradability of dietary protein on lactation, nitrogen utilization, and excretion in early lactation Holstein cows. Journal of Dairy Science., 86; 1681-1689.

Dehority, B.A. (2003). Rumen Microbiology. Nottingham University Press Nottingham, UK.

Duncan, D.B. (1955). Multiple range and multiple F tests. Biometrics 11, 1-42.

Eadie, J.M., P. Hobson and S. Mann (1967). A note on some comparisons between the rumen content of barley-fed steers and that of young calves also fed on a high concentrate ration. Animal Science., 9; 247-250.

France, J., J. Dijkstra, M. Dhanoa, S. Lopez and A. Bannink (2000). Estimating the extent of degradation of ruminant feeds from a description of their gas production profiles observed in-vitro: derivation of models and other mathematical considerations. British Journal of Nutrition., 83; 143-150.

Giannenas, I., J. Skoufos, C. Giannakopoulos, M. Wiemann, O. Gortzi, S. Lalas and I. Kyriazakis (2011). Effects of essential oils on milk production, milk composition, and rumen microbiota in Chios dairy ewes. Journal of Dairy Science., 94; 5569-5577.

Giller, K., T. Rilko, E. Manzocchi, S. Hug, R. Bolt and M. Kreuzer (2020). Effects of mixed essential oils from eucalyptus, thyme and anise on composition, coagulation properties and antioxidant capacity of the milk of dairy cows. Journal of Animal and Feed Sciences., 29; 3-10.

Goering, H., and P.J.Van Soest (1970). Forage fiber analysis. Agricultural handbook no. 379. US Department of Agriculture, Washington, DC, 1-20. 
Hristov, A., C. Lee, T. Cassidy, K. Heyler, J. Tekippe, G. Varga, B. Corl and R. Brandt (2013). Effect of Origanum vulgare L. leaves on rumen fermentation, production, and milk fatty acid composition in lactating dairy cows. Journal of Dairy Science., 96; 1189-1202.

Kırkpınar, F., H.B.,Ünlü and G. Özdemir (2011). Effects of oregano and garlic essential oils on performance, carcase, organ and blood characteristics and intestinal microflora of broilers. Livestock Science., 137; 219-225.

Kearl, L. C. (1982). Nutrient Requirements of Ruminants in Developing countries. International Feedstuff Institute, Utah Agricultural Experiment Station, Utah State University, Logan, Utah, USA.

Lammari, N., O. Louaer, A.H. Meniai and A. Elaissari (2020). Encapsulation of essential oils via nanoprecipitation process: Overview, progress, challenges and prospects. Pharmaceutics., 12; 431.

Maes, C., S. Bouquillon and M.L. Fauconnier (2019). Encapsulation of essential oils for the development of biosourced pesticides with controlled release: A review. Molecules., 24; 2539.

Malekkhahi, M., A.M. Tahmasbi, A.A. Naserian, M. Danesh Mesgaran, J. Kleen and A. Parand (2015). Effects of essential oils, yeast culture and malate on rumen fermentation, blood metabolites, growth performance and nutrient digestibility of Baluchi lambs fed high-concentrate diets. Journal of animal physiology and animal Nutrition., 99; 221-229.

Manh, N., M. Wanapat, S. Uriyapongson, P. Khejornsart and V. Chanthakhoun (2012). Effect of eucalyptus (Camaldulensis) leaf meal powder on rumen fermentation characteristics in cattle fed on rice straw. African Journal of Agricultural Research., 7;2142-2148.

McIntosh, F., P. Williams, R. Losa, R. Wallace, D. Beever and C. Newbold (2003). Effects of essential oils on ruminal microorganisms and their protein metabolism. Applied and environmental microbiology., 69; 5011-5014.

Morsy, T., S. Kholif, O. Matloup, M. Abdo and M. El-Shafie (2012). Impact of anise, clove and juniper oils as feed additives on the productive performance of lactating goats. International Journal of Dairy Science., 7; 20-28.

Nguyen, H., E.M. Campi, W.R. Jackson and A.F. Patti (2009). Effect of oxidative deterioration on flavour and aroma components of lemon oil. Food Chemistry., 112; 388-393.

Patra, A., and J.Saxena (2009). The effect and mode of action of saponins on the microbial populations and fermentation in the rumen and ruminant production. Nutrition Research Reviews., 22; 204-219.

Patra, A.K., and J. Saxena (2010). A new perspective on the use of plant secondary metabolites to inhibit methanogenesis in the rumen. Phytochemistry., 71; 1198-1222.

Patra, A.K., Z. Yu (2012). Effects of essential oils on methane production and fermentation by, and abundance and diversity of, rumen microbial populations. Applied and Environmental Microbiology., $78 ; 4271-4280$

Pellikaan, W. F., Hendriks, W. H., Uwimana, G., Bongers, L. J. G. M., Becker, P. M., and J. W.Cone(2011). A novel method to determine simultaneously methane production during in vitro gas production using fully automated equipment. Animal Feed Science and Technology., 168(3-4) ; 196205.

Raafat, M.A. and M.S. Saleh (1962). Two formulas for conversion of cows and buffaloes milk of different fat percentage into milk standard fat percentage. Proceedings of the 1st Animal Production Conference, (APC'62), Minia., pp: 203-.

Sallam, S.M., I.C. Bueno, M.E. Nasser and A.L. Abdalla (2010). Effect of eucalyptus (Eucalyptus citriodora) fresh or residue leaves on methane emission in-vitro. Italian Journal of Animal Science., 9; e58.

Santos, M., P. Robinson, P. Williams and R. Losa (2010). Effects of addition of an essential oil complex to the diet of lactating dairy cows on whole tract digestion of nutrients and productive performance. Animal Feed Science and Technology., 157; 64-71.

SAS, (2009). SAS/STAT User's Guide. SAS Institute Inc, Cary, NC.

Schneider, B.H., and W.P. Flatt (1975). The evaluation of feeds through digestibility experiments. University of Georgia Press. 
Sebei, K., F. Sakouhi, W. Herchi, M.L. Khouja and S. Boukhchina (2015). Chemical composition and antibacterial activities of seven Eucalyptus species essential oils leaves. Biological research., 48; 1-5.

Spanghero, M., P. Robinson, C. Zanfi and E. Fabbro (2009). Effect of increasing doses of a microencapsulated blend of essential oils on performance of lactating primiparous dairy cows. Animal Feed Science and Technology., 153; 153-157.

Tassoul, M., and R. Shaver (2009). Effect of a mixture of supplemental dietary plant essential oils on performance of periparturient and early lactation dairy cows. Journal of Dairy science., 92; 17341740.

Thao, N., M. Wanapat, A. Cherdthong and S. Kang (2014). Effects of eucalyptus crude oils supplementation on rumen fermentation, microorganism and nutrient digestibility in swamp buffaloes. Asian-Australasian Journal of Animal Sciences., 27; 46.

Thao, N., M. Wanapat, S. Kang and A. Cherdthong (2015). Effects of supplementation of eucalyptus ( $E$. camaldulensis) leaf meal on feed intake and rumen fermentation efficiency in swamp buffaloes. Asian-Australasian Journal of Animal Sciences., 28; 951.

Theodorou, M.K., B.A. Williams, M.S. Dhanoa, A.B. McAllan and J. France (1994). A simple gas production method using a pressure transducer to determine the fermentation kinetics of ruminant feeds. Animal Feed Science and Technology., 48; 185-197.

Turek, C., and F.C. Stintzing (2013). Stability of essential oils: a review. Comprehensive reviews in food science and food safety., 12; 40-53.

Vakili, A., B. Khorrami, M.D. Mesgaran and E. Parand (2013). The effects of thyme and cinnamon essential oils on performance, rumen fermentation and blood metabolites in Holstein calves consuming high concentrate diet. Asian-Australasian Journal of Animal Sciences., 26; 935.

Van Keulen, J., and B. Young (1977). Evaluation of acid-insoluble ash as a natural marker in ruminant digestibility studies. Journal of Animal Science., 44; 282-287.

Van Soest, P.V., J. Robertson and B. Lewis (1991). Methods for dietary fiber, neutral detergent fiber, and nonstarch polysaccharides in relation to animal nutrition. Journal of Dairy Science., 74; 3583-3597.

Wall, E.H., P.H. Doane, S.S. Donkin and D. Bravo(2014). The effects of supplementation with a blend of cinnamaldehyde and eugenol on feed intake and milk production of dairy cows. Journal of Dairy science., 97; 5709-5717.

Wanapat, M., A. Ngarmsang, S. Korkhuntot, N. Nontaso, C. Wachirapakorn, G. Beakes and P. Rowlinson (2000). A comparative study on the rumen microbial population of cattle and swamp buffalo raised under traditional village conditions in the northeast of Thailand. Asian-Australasian Journal of Animal Sciences., 13; 918-921.

Wang, C., S. Wang and H. Zhou (2009). Influences of flavomycin, ropadiar, and saponin on nutrient digestibility, rumen fermentation, and methane emission from sheep. Animal Feed Science and Technology., 148; 157-166.

Yang, W., B. Ametaj, C. Benchaar and K. Beauchemin (2010a). Dose response to cinnamaldehyde supplementation in growing beef heifers: ruminal and intestinal digestion. Journal of Animal Science., $88 ; 680-688$.

Yang, W., B. Ametaj, C. Benchaar, M. He and K. Beauchemin (2010b). Cinnamaldehyde in feedlot cattle diets: intake, growth performance, carcass characteristics, and blood metabolites. Journal of Animal Science., 88; 1082-1092. 


\title{
تأثير إضافة أوراق ويذور وزيت الكافور على إنتاجية الجاموس المصري الحلاب وإنتاج الميثان
}

\author{
فوزى محم أبودنيا1، ، عبد المنعم محجوب1 ، طارق دراز و أسامه أبو العز نايل2

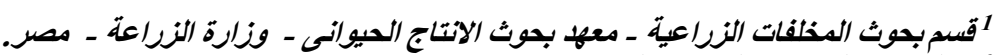 \\ 2 كلية النزراعة - جامعة المنوفية - مصر.
}

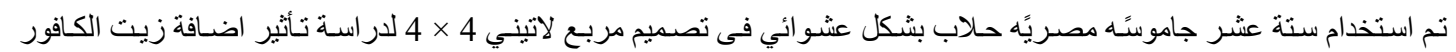

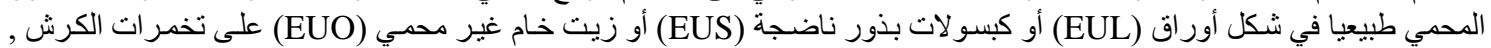

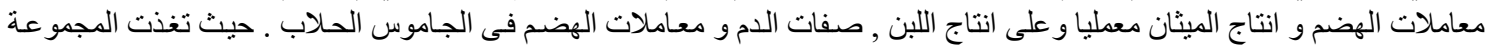

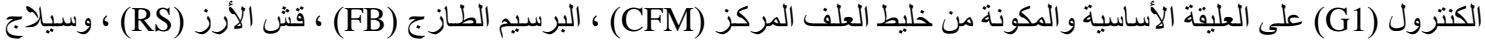

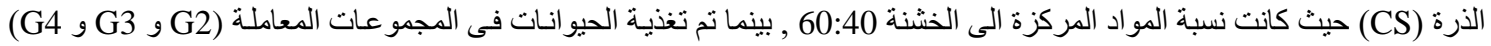

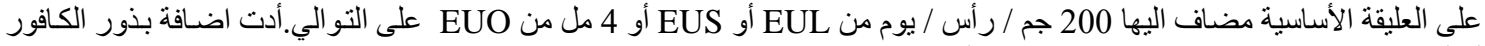

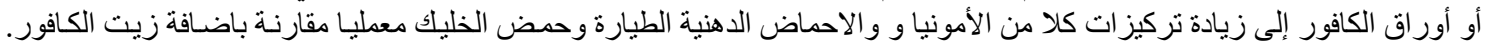

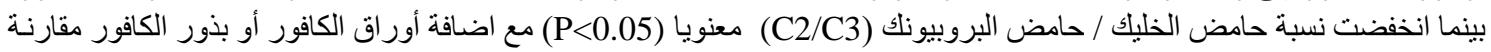

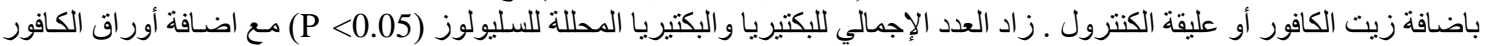

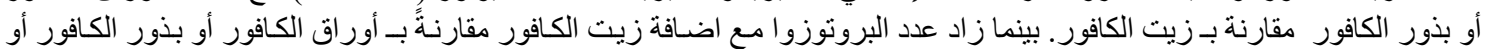

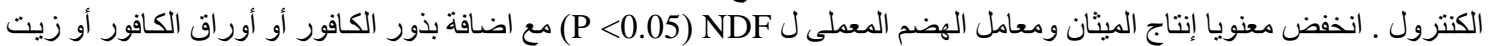

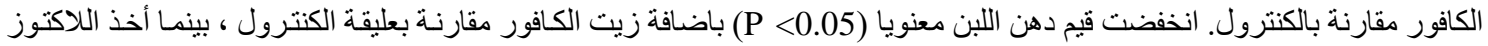

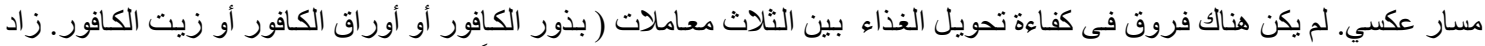

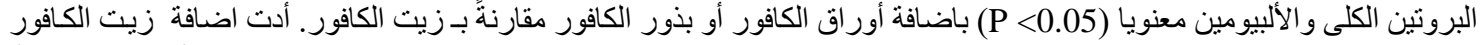

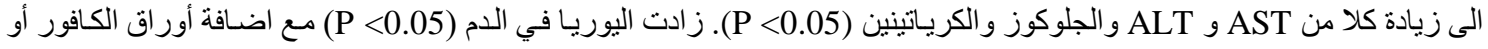

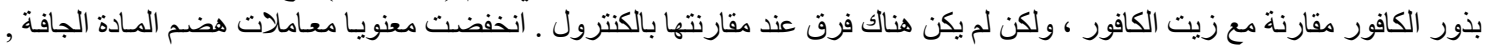

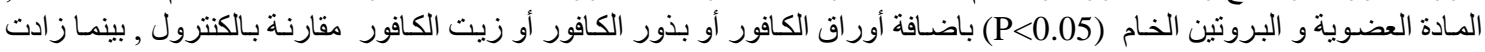

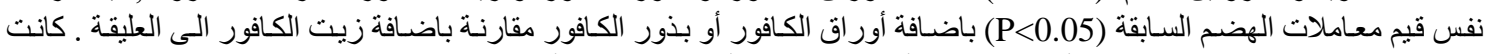

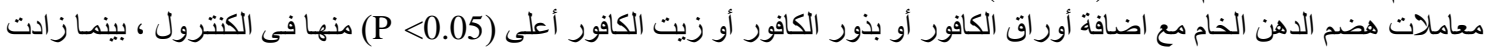



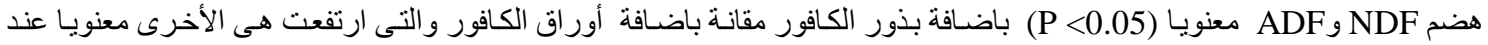

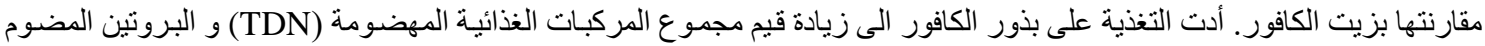
(DCP)

فلى النهاية تؤكد نتائج الدراسة الحالية أن اضافة زيت الكافور المحمي بشكل طبيعي في شكل أوراق أو أو بذور يخفف من الآثار السلبية لاضافة زيت الكافور الخام بشكل مباثر. 